\title{
Comprehensive sex education. The role of pediatricians
}

Sexuality, understood as the way a person perceives themselves, expresses, and relates to other people, is multidimensional. It is not limited to appearance or to having physical relationships with other people, but it entails a person's identity, social role, romance, and emotions. Such perspective, that is nowadays more comprehensive than in the past, is useful to understand that this is not something that comes up during puberty, with the changes typical of sexual development, but that is present throughout our lifetime.

The right to the highest attainable standard of health, as established by the Convention on the Rights of the Child, necessarily includes comprehensive sex education. Moreover, it is relevant to protect other rights set out by the Convention: education, equity, and inclusion. ${ }^{1}$

Sex education implies promoting the exercise of rights and, consistent with this, it addresses the need to work on different social problems affecting childhood today. Such problems include child sexual abuse, which is not recorded in Argentina, but was the reason for more than 2000 police reports in 2017. More than $50 \%$ of child sexual abuse cases take place in the child's home, and $70 \%$ are carried out by someone within the family circle. ${ }^{2}$ There are other right violation modalities, such as intrafamily violence, even as a form of discipline, which affects $70 \%$ of children and adolescents in our country. ${ }^{3}$ Such adverse circumstances have a great impact during childhood, but are also associated with the development of multiple health problems as adults. Since these situations are more common in the family setting, it is imperative to offer tools and support to every child in formal and nonformal learning environments, where educators emerge as the defenders of rights. This is exactly the same role that health care providers have to play because we also share the responsibility given the nature of our duties and because, from a legal perspective, we need to advocate the wellbeing of our patients. ${ }^{4}$

The problems addressed by comprehensive sex education also include adolescent pregnancy and parenthood. In Argentina, $16 \%$ of all births correspond to babies of mothers younger than 20 years old. Every year, 3000 girls younger than 15 years old become mothers. ${ }^{3}$ The negative implications of this not only affect the girls' and their babies' health, but also their education and social setting.

Another alarming thematic focus concerns sexually transmitted diseases (STDs). Although practically all adolescents received information about HIV infection and the rate of HIV transmission tends to a reduction, the rate of reporting of other STDs has been continuously rising for some years now. For example, the rate of reporting of early syphilis tripled between 2013 and 2017. ${ }^{5}$

School violence, a phenomenon that affects 1 in every 3 students, is also a relevant topic because it concerns a person's integrity and respect for others. Some forms of peer violence, through the use of communication and information technologies, now a frequent interaction modality between children and adolescents, require media literacy to avoid an improper use that may lead to cyberbullying and sexting situations. Many of these situations are the result of gender norms and stereotypes. ${ }^{6}$

All the problems described here share a common denominator that may be summarized in two words: rights violation. Based on this, it is necessary to warrant knowledge, the development of self-protection skills, and the provision of a space of listening that would allow to detect and take action in these situations in pursuit of children's best interest.

In Argentina, Law no. 26150 established, in 2006, the Comprehensive Sex Education Program. ${ }^{7}$ The purpose of this law is also that of the Law for the Comprehensive Protection of the Rights of Children and Adolescents (Law no. 26061) and is consistent with that of the UNESCO technical guidance. The comprehensive sex education program is targeted at establishing a cross-sectional approach across all school subjects, not only one. As part of its thematic focuses, it considers the knowledge of one's rights and the respect for the rights of others, the recognition of people as subjects who are different from one another but who have the same rights, the expression of and reflection about emotions and relationships, a person's own identity, the responsibility for and knowledge of self-care, personal and reproductive life plans, and the prevention of abuse, maltreatment, and violence. This way, comprehensive sex education is not restricted to explaining risks or diseases; it also 
encompasses different aspects of a person's wellbeing at different times of their lives, in relation to themselves and others. ${ }^{8}$

International guidelines on this topic make an allusion to progressive education, in accordance with students' age and based on scientific evidence, relevant for the cultural setting and with an approach to legal rights. ${ }^{8}$ Therefore, unlike what is sometimes perceived as a concern by some families, it is a respectful approach to individuality. The scope of application necessarily requires the school, but this does not exclude the family or non-formal learning environments. This is easily understood when considering that most right violation situations take place in the family setting, on the one side, and that the State is bound, by law, to warrant the exercise of children's rights. ${ }^{6}$

In spite of the foregoing, there is still controversy among the different members of the community about whether it is adequate and beneficial to offer such tools in the school setting. Such concerns are well-meaning, but are probably rooted in the fact that some childhood and adolescence problems are still not seen with the importance, characteristics, and urgency that they truly have, and also because of the lack of truthful information and solid knowledge about the topic. Sometimes, contrary to the current paradigm, children are still seen as an object of protection, and not as an actual subject of rights towards whom adults have responsibilities.

Two concerns are usually stated: that comprehensive sexual education programs will result in an earlier sexual initiation and that they will influence children's and adolescents' identity and / or sexual orientation. About the latter, there are no studies about the effect of programs; however, there is evidence that the sexual orientation of the parents, the first and fundamental educators, does not influence children's identity and sexual orientation. ${ }^{9}$ In relation to effectiveness, studies have demonstrated that comprehensive sexual education programs lead to a reduction in risky behaviors (delayed sexual initiation, lower number of sex partners, and safe sex).$^{10}$ There are still no results about the other aspects involved in the comprehensive nature of these programs, whose study requires a longer follow-up period.

In this setting, it is necessary for us, as pediatricians, to offer a professional response to the needs of both children and their families and of other health care providers. It is not only necessary to learn what these education programs actually propose on this topic and about the experiences developed in other regions, but also to keep our knowledge up-to-date in a search for the best available scientific evidence so that we may use it to support families in the different stages of upbringing, accompany our patients' growth and comprehensive development by respecting their individuality, and advocate, in our everyday practice, the full exercise of children's and adolescents' rights.

María Elina Serra, M.D.

Health Prevention Program for Child Care Centers.

Fundación para la Salud Materno Infantil (FUNDASAMIN), Autonomous City of Buenos Aires, Argentina.

http: / / dx.doi.org/10.5546/ aap.2020.eng.84

Tocite:Serra ME. Comprehensive sex education. The role of pediatricians. Arch Argent Pediatr 2020;118(2):84-86.

\section{REFERENCES}

1. Asamblea General de las Naciones Unidas. Convención de los Derechos del Niño, Noviembre de 1989. Madrid: UNICEF; 2006. [Accessed on: October $7^{\text {th }}, 2019$ ]. Available at: https: / / www.un.org/es / events / childrenday/pdf/ derechos.pdf

2. Programa Víctimas de Violencia. Estadísticas sobre abuso sexual infantil en la Argentina. 2016. [Accessed on: October $\left.1^{\text {st }}, 2019\right]$. Available at: https: / / www.argentina.gob.ar/ abusosexualinfantil/estadisticas

3. UNICEF. Estado desituación de la niñezy la adolescencia en Argentina. 2016. [Accessed on: October $4^{\text {th }}$, 2019]. Available at:https: / / www.unicef.org/argentina/media/2211/file/ SITAN.pdf

4. Ley Nacional 26.062/05. Ley de Protección Integral de los Derechos de las Niñas, Niños y Adolescentes. Buenos Aires, 21 de octubre de 2005. [Accessed on: October $\left.3^{\text {rd }}, 2019\right]$. Available at: https://www.oas.org/dil/esp/ Ley_de_Proteccion_Integral_de_los_Derechos_de_las_ Ninas_Ninos_y_Adolescentes_Argentina.pdf

5. Argentina. Ministerio de Salud y Desarrollo Social. Boletín sobre el VIH, sida e ITS en la Argentina. 2018;21(35). [Accessed on:October $\left.4^{\text {th }}, 2019\right]$. Available at: http: / / www. msal.gob.ar/images / stories / bes / graficos / 0000001385c nt-2018-12-20_boletin-epidemiologico-vih-sida-its_n35.pdf

6. Orientaciones internacionales para abordar la violencia de género en el ámbito escolar. Paris: ONU/UNESCO; 2019. [Accessed on: October $\left.4^{\text {th }}, 2019\right]$. Available at: https: / / unesdoc.unesco.org/ark: / 48223/pf0000368125/ PDF/368125spa.pdf.multi

7. Ministerio Nacional de Educación. Programa Nacional de Educación Sexual Integral. Lineamientos Curriculares para la Educación Sexual Integral Ley Nacional N² 26.150. 2018. [Accessed on:October $4^{\text {th }}$, 2019]. Available at: https: / / www. argentina.gob.ar/sites / default / files / lineamientos_0.pdf 
8. UNESCO, Programa Conjunto de las Naciones Unidas sobre el VIH/SIDA, Fondo de Población de las Naciones Unidas, Fondo de las Naciones Unidas para la Infancia, et al. International technical guidance on sexuality educationEvidence-Informed Approach. Paris: UNESCO; 2018. [Accessed on: October 1st, 2019]. Available at: https:/ / unesdoc.unesco.org/ark: / 48223/pf0000260770

9. Tasker F. Lesbian mothers, gay fathers, and their children: a review. I Dev Behav Pediatr. 2005; 26(3):224-40.

10. Fondo de Publicaciones de las Naciones Unidas. Directrices operacionales del UNFPA para la educación integral de la sexualidad: un enfoque basado en los derechos humanos y género. Nueva York: UNFPA; 2014. [Accessed on: October 1st, 2019]. Available at: https:// www.unfpa.org/sites/default/files / pub-pdf/UNFPA_ OperationalGuidanceREV_ES_web.pdf

\section{The new Nosology and classification of genetic skeletal disorders}

In the last four-month period of 2019, the American Journal of Medical Genetics published the new Nosology and classification of genetic skeletal dysplasias, which had been greatly anticipated by primary care physicians. The publication groups these disorders by phenotype and molecular basis. Therefore, their nature still constitutes a "hybrid" system because the same criterion is not always strictly applied. Some conditions are grouped based on the causative gene, others share common radiological features, a similar clinical course (lethality) or the involvement of similar skeletal parts.

A group of experts in Radiology, Orthopedic Surgery, Pediatrics, and Genetics met in Paris 50 years ago and proposed to develop the International Nomenclature of Constitutional Disorders of Bone in order to reach an agreement about the different skeletal disorders. The experts presented a large body of evidence regarding heterogeneity, which was highly valued by the medical community, who started to perceive the diversity in terms of clinical and radiological findings, and it became clear that not all subjects with short limbs suffer achondroplasia (OMIM 100800) and also that not all subjects with a short trunk have Morquio syndrome or mucopolysaccharidosis type 4 (OMIM 25300 and 253010). Several meetings were held until, 30 years later, in 1999, the International Skeletal Dysplasia Society (ISDS) was established, whose nomenclature reviews (nosology) were delegated to the Committee experts designated from within the Society, which offers a combination of clinical, radiological, and genetic experience. The experts, progressively submitted their reviews. The most recent review is the $10^{\text {th }}$ edition of the Nosology and classification of genetic skeletal disorders. ${ }^{1}$

It encompasses 461 disorders divided into 42 different groups. ${ }^{1}$ The prior classification (2015) included 436 disorders and the same number of groups, ${ }^{2}$ but two of them (18 and 19) have changed their name. There are 437 genes currently mentioned in 425 disorders, accounting for $92 \%, 1$ compared to $58 \%$ in 2006 . $^{3}$

It is worth noting the following:

- Different pathogenic variants in a gene may cause different phenotypes, for example: (group 1), called FGFR3 chondrodysplasia, a set of disorders caused by mutations in the FGFR3 gene and whose different mutations (allelic genetic heterogeneity) may lead to thanatophoric dysplasia type 1 and 2 (OMIM 187600 and 187601, respectively), hypochondroplasia (OMIM 146000), severe achondroplasia with developmental delay and acanthosis nigricans (SADDAN) (OMIM 616482), and camptodactyly, tall stature and hearing loss syndrome (CATSHL) (OMIM 610474). Except for the latter, all these disorders have an autosomal dominant inheritance pattern; the CATSHL syndrome may show an autosomal dominant or recessive inheritance pattern. In addition to the disorders mentioned above, there are 33 different craniosynostosis syndromes linked to FGFR3 mutations, such as LADD syndrome (OMIM 149730) and 41 diverse phenotypes.

Group 33, called craniosynostosis syndromes, includes Crouzon-like craniosynostosis with acanthosis nigricans (OMIM 612247), Muenke 